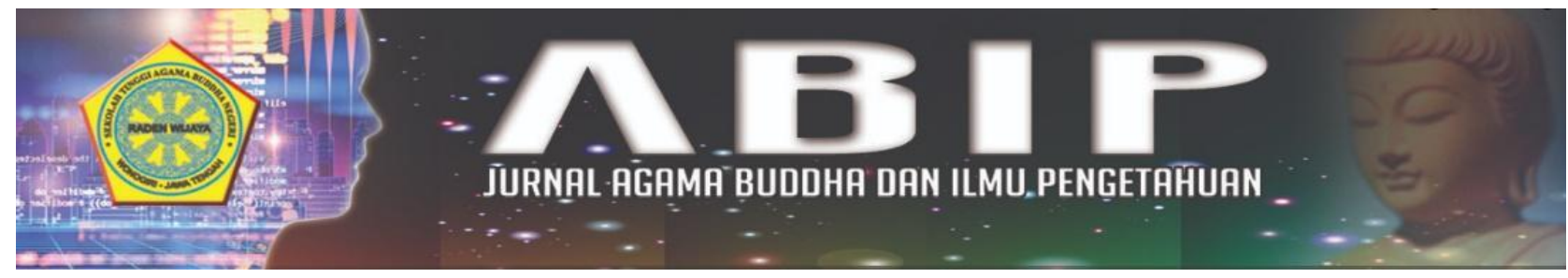

\title{
DAMPAK PANDEMI COVID-19 TERHADAP KEGIATAN KEAGAMAAN DI VIHĀRA DHAMMADĪPA SURABAYA
}

\author{
Shehilla Diana Lawrenza \\ Sekolah Tinggi Agama Buddha (STAB) Kertarajasa \\ enzajata@gmail.com
}

\begin{abstract}
Abstrak
Latar belakang masalah penelitian adalah sejauhmana perubahan sebelum dan selama adanya pandemi Covid-19 terjadi terhadap kegiatan Keagamaan. Pandemi Covid-19 yang terjadi di Indonesia yang mengakibatkan aktivitas menjadi terbatas. Penyebaran virus di tingkat dunia memaksa Pemerintah Republik Indonesia untuk melakukan kebijakan. Tujuan dari penelitian adalah untuk mengetahui dampak pandemi Covid-19 terhadap kegiatan keagamaan di Vihāra Dhammadīpa Surabaya. Penelitian dilakukan menggunakan metode kualitatif deskriptif. Penelitian difokuskan pada kegiatan keagamaan rutin dilakukan secara offline kemudian diganti dengan online. Sumber data penelitian didapatkan dari hasil wawancara yang dilakukan terhadap 6 orang informan. Data dukungannya berupa literatur, kajian reseach sebelumnya, buku pustaka, foto dan sumber media secara online. Teknik pengumpulan data tersebut diperoleh melalui teknik observasi, wawancara, dan dokumentasi. Hasil dari penelitian ini menunjukkan bahwa kegiatan yang ada di Vihāra menurun karena adanya pandemi Covid-19. Cara pandang umat terhadap keagaaman mengalami perubahan drastis seperti spiritual, psikologis dan perubahan waktu serta tempat saat beribadah.
\end{abstract}

Kata kunci: Dampak Pandemi, Covid-19, Kegiatan Keagamaan

\begin{abstract}
The background of the research problem is the extent to which changes before and during the Covid19 pandemic occurred in religious activities. The Covid-19 pandemic that occurred in Indonesia resulted in limited activities. The spread of the virus at the world level forced the Government of the Republic of Indonesia to carry out policies. The purpose of the study was to determine the impact of the Covid-19 pandemic on religious activities at Vihära Dhammadīpa Surabaya. The research was conducted using descriptive qualitative methods. The research focused on routine religious activities carried out offline and then replaced with online. Sources of research data obtained from the results of interviews conducted with 6 informants. Supported data in the form of literature, previous research studies, library books, photos and online media sources. The data collection techniques were obtained through observation, interviews, and documentation techniques. The results of this study indicate that the activities at the Vihära have decreased due to the Covid-19 pandemic. People's perspective on religion has undergone drastic changes such as spiritual, psychological and changes in time and place of worship.
\end{abstract}

Keywords: Pandemic Impact, Covid-19, Religious Activities 


\section{PENDAHULUAN}

Dunia digemparkan dengan menyebarnya virus baru yaitu corona virus, dari kasus misterius yang pertama kali muncul dikaitkan di pasar Wuhan, China. Sejak 31 Desember 2019 hingga Januari 2020 kasus ini meningkat dengan pesat. Tidak sampai satu bulan, virus ini menyebar di berbagai negara lainnya Thailand, Jepang, dan Korea Selatan. Awalnya penyakit ini sementara dinamakan sebagai 2019 novel corona virus (2019nCov). Kemudian telah ditetapkan oleh WHO sebagai pandemi pada maret 2020. Virus penyebab Covid-19 ini dinamakan Sars-Cov-2. Corona virus adalah zoonosis (ditularkan antara hewan dan manusia). Virus ini merupakan keluarga besar virus yang dapat menyebabkan penyakit, mulai dari flu biasa hingga penyakit yang lebih parah, seperti MERS dan SARS (de Wit E, 2016).

Hal ini berdampak di negara-negara lain hingga disebut darurat kesehatan Global. Pemerintah juga melarang kepada masyarakat untuk tidak meninggalkan rumah, membatasi perkumpulan di tempat umum seperti tempat ibadah, kampus, pasar, mall dan sebagainya. Peraturan tersebut berlaku dalam kegiatan seharihari diberbagai profesi disetiap wilayah serta tempat-tempat tertentu mulai dilock down. Sementara Covid-19 juga mempengaruhi kegiatan keagamaan, dimana kegiatan merupakan salah satu faktor untuk mengondisikan pikiran dan jiwa manusia serta menentramkan kehidupan. Akan tetapi, kegiatan justru mengubah menjadi pembatasan. Pembatasan tersebut memunculkan dampak perubahan yang pesat disebabkan karena sebuah aktivitas yang biasa dilakukan dengan baik kemudian terhambat mulai dari aktivitas kimia, fisik, biologi maupun aktivitas manusia menurut Otto Soemarwoto (1998:43). Dari dampak sendiri memiliki 2 (dua) jenis yaitu positif dan negatif. Selama adanya perubahan dari kondisi dan situasi ini, untuk pelaksanaan kegiatan keagamaan diselenggarakan secara virtual agar tidak menjadi media penyebaran Covid-19.

Surabaya salah satu kota besar memiliki populasi penduduk lumayan padat dan banyak umat Buddha. Begitu dengan Vihāra yang ada di Surabaya ini adalah tempat ibadah umat Buddha yang sering melaksanakan kegiatan kaagaman seperti Seminar, Dhammadesana, maupun Sekolah Minggu Buddha dan kegiatan lainnya.
Kegiatan tersebut terlihat sedikit terhambat pada saat pandemi dan pola kegiatannya diganti secara Virtual. Sehingga Covid-19 mempengaruhi penghambatan kegiatan keagamaan di Vihāra Dhammadīpa Pandegiling (Vihāra Dhammadīpa, 2019).

Berdasarkan pernyataan salah satu pengurus sekretaris Vihāra Dhammadīpa di Surabaya, Ibu Widyawati menjelaskan bahwa Selama seminggu di Vihāra memang memiliki jadwal khusus. Mengenai kegiatan keagamaan sebelum pandemi yaitu mengadakan puja bakti umum, dhammadesana, meditasi, sunschool, dana makan, akupuntur gratis, dan baksos berjalan dengan baik dan lancar. Sedangkan selama pandemi dari pihak pemerintah menghimbau terhadap masyarakat tidak ada yang mengunjungi tempat-tempat khusus seperti Vihāra maupun keramaian sehingga ada tindakan pelaksanaan PSBB.Dipertengahan pandemi kegiatan keagamaanpun beberapa bulan terhenti dan ditiadakan. Pada bulan April lalu di Vihāra mulai melaksanakan kegiatan yaitu berbagi nasi bungkus untuk ojek online, tukang becak, dan tukang sapu yang lewat di depan Vihāra. (Wawancara/interview bebas via WhatsApp dengan Ibu Widyawati pada tanggal 15 Februari 2020, 15.08 WIB).

Bhante Jayamedho Thera selaku Ketua Yayasan Vihāra Dhammadīpa juga menjelaskan bahwa untuk memulai kegiatan ada dua bagian yaitu yang pertama berada di dalam Vihāra, umat yang datang terbatas biasa maksimal 50 saat ini hanya 20 orang dan yang kedua dilaksanakan secara virtual. Seperti bulan lalu mengadakan perayaan Kathina kegiatan dilaksanakan sesuai protokol dan physical distancing. (Wawancara secara langsung, Bhante Jayamedho Thera pada tanggal 17 Februari 2020, 06.51 WIB).

Dari uraian diatas berdasarkan fenomena yang terjadi, maka peneliti tertarik melakukan penilitian tentang dampak pandemi covid-19 terhadap kegiatan keagamaan khususnya di Vihāra Dhammadīpa Surabaya. Lebih lanjutnya yang diteliti tentang masalah kegiatan, keaktifan umat dan kondisi umat yang ada di Vihāra Dhammadīpa, Dengan demikian peneliti mengambil judul penelitian "Dampak Pandemi Covid-19 terhadap Kegiatan Keagamaan di Vihāra Dhammadipa Surabaya". 


\section{METODE}

Pendekatan yang digunakan dalam penelitian ini adalah deskriptif kualitatif.. Penelitian ini dilaksanakan di Vihāra Dhammadīpa, Jl. Pandegiling No. 260, Wonorejo, Tegalsari, Kota Surabaya, Jawa Timur, 60264 dimana melihat perubahan kegiatan keagamaan selama pandemi Covid-19. Dalam penelitian ini, sumber data yang akan digunakan oleh peneliti ada dua yaitu: data primer dan data sekunder. Teknik pengumpulan data menggunakan wawancara, observasi, dan dokumentasi. Teknik analisis data yang digunakan penelitian adalah teknik analisis data model interaktif yang ditawarkan (Miles, Huberman, dan Saldana, 2014:12-14) melalui tiga tahap: Kondensasi Data (data condensation), Penyajian Data (data display), Penarikan Kesimpulan (conclusions drawing), Untuk keabsahan data, peneliti menggunakan salah satu teknik triagulasi, yaitu triagulasi sumber yakni membandingkan hasil wawancara dengan isi dokumen yang terkait, sehingga mudah untuk memeriksa kembali yang sudah terkumpul (Hasan, dkk, 2003:133-134).

\section{HASIL}

Hasil penelitian diperoleh melalui teknik observasi, wawancara dan dokumentasi dengan cara terjun langsung ke lapangan guna mendapat data yang lebih valid. Setelah semua data terkumpul, maka data tersebut diolah dan kemudian dianalisis. Analisis ini berfokus pada keadaan dan kegiatan yang dilaksanakan di Vihāra Dhammadipa selama Pandemi COVID-19.

\section{Vihāra Dhammadīpa Surabaya}

Vihara Dhammadipa memiliki umat Buddha yang aktif saatini dalam melakukan kegiatan keagamaan dan sosial. Vihara ini adalah tempat dimana dulu salah satu ruko kemudian muncul lah sebuah gagasan luhur untuk mendirikan sebuah tempat ibadah agama Buddha di Surabaya. Dengan semangat dan niat yang baik membentuk Cetya Karunadipa yang berada di Jalan Telasih 16 untuk pertama kalinya, usaha mulia ini didukung oleh Yang Mulia Bhikkhu Sangha. Dengan awal keadaan tempat kurang memadai, hal ini memunculkan ide untuk mengumpulkan dana. Setelah dana terkumpul membeli sebuah tempat yang berada di jalan Pandegiling, Selain itu pada tanggal 07 Januari 1993 Cetya Karunadipa berubah menjadi Vihāra Dhammadīpa yang mana yaitu cabang dari Vihāra Dhammadīpa Arama di kota Batu-Malang Kepala Vihāra oleh YM. Viriyadharo Mahathera, wakil Vihāra YM. Sukhito Mahathera.

Pada bulan Februari 2005 Vihāra Dhammadīpa yang berada di Jl. Pandegiling No. 260, Wonorejo, Tegalsari, Kota Surabaya, Jawa Timur. Di renovasi yang awal terlihat seperti ruko menjadi bangunan yang sesuai dengan standar Vihāra, yang meliputi beberapa kuti, ruang untuk sekolah minggu dan Dhammasala yang lebih luas serta aula serbaguna. Serta bangunan baru ini segala kegiatan rutin yang biasa dilaksanakan di Vihāra Dhammadīpa dapat terlaksana dengan lancar dan baik. Pada tanggal 01 Februari 2009 Vihāra Dhammadīpa resmi dibawah naungan Sangha Theravada Indonesia (STI). Saat ini kepala Vihāranya adalah YM. Jayamedho Thera, Vihāra ini juga memiliki kegiatan-kegiatan yang luar biasa di dalam kegiatan keagamaan Buddha maupun sosial.

\section{Kegiatan Keagamaan di Vihāra Dhammadīpa Surabaya Sebelum dan Selama Pandemi Covid-19}

Kegiatan keagamaan terdiri dari dua kata yaitu kegiatan dan keagamaan. Kegiatan adalah suatu aktivitas, usaha, peristiwa atau kejadian yang dilakukan oleh seseorang secara langsung dan terus-menerus. Keagamaan adalah sistem yang mengatur tata keimanan (kepercayaan) dan peribadatan kepada Tuhan Yang Maha Esa serta tata kaidahnya yang berhubungan dengan perkumpulan manusia. Kegiatan keagamaan suatu penyebaran ajaran dengan serangkaian proses melalui upaya dan pengubahan kesadaran dari sebuah perilaku pada manusia kearah yang lebih baik terpadu, berilmu serta memiliki akhlak yang baik. Kegiatan keagamaan Buddha dilakukan oleh umat Buddha untuk mengembangkan spriritual (dalam batin) dan mengajarkan kebajikan yang luar biasa yaitu beribadatan ialah beriman dan bersujud kepada Tuhan Yang Maha Esa, memuliakan para suci Tiratana (Buddha, Dhamma, dan Sangha) serta ajaran-Nya didalam semangat luhur dan baktinya meliputi beberapa hal sebagai berikut : Pelaksanaan kegiatan keagamaan yang dilaksanakan setiap hari di Vihāra Dhammadipa Surabaya. Hanya beberapa umat yang datang ke Vihāra dengan ibadah dengan berbeda-beda kegiatan. Kegiatan rutin sebelum 
adanya pandemi covid-19 dapat digambarkan sebagai berikut: melaksanakan ibadah atau Pujabakti umum, Dhammadesana, Meditasi, Sunschool anak-anak dan remaja, Pattidana, Dana makan, Akupuntur gratis, Ritual nikah, Bakti Sosial, Fangshen serta pada hari besar seperti hari raya Māgha Pūja, Vaisak, Asadha, dan Kathina. Sebelum pandemi kegiatan dilakukan bersamasama dan secara offline dengan lancar dan tidak ada hambatan serta batasan apapun. Kemudian selama pandemi kegiatan tersebut dilakukan secara virtual adapun kegiatan yang dapat dilakukan secara offline namun umat yang menghadiri sangatlah terbatas dan harus sesuai protokol kesehatan.

\section{Dampak Pandemi Covid-19 Terhadap Kegiatan Keagamaan di Vihāra Dhammadīpa Surabaya}

Menghadapi wabah Covid-19 terdapat banyak aspek yang terkena dampak dari Covid-19, yaitu kegiatan agama diantaranya adalah didalam tata cara ibadah dalam agama, salah satunya Agama Buddha yang terjadi di Vihāra Dhammadipa Surabaya. Yang mana pada saat ini kita mengetahui wabah dari covid-19 ini bukan hanya merenggut ribuan nyawa manusia, tetapi juga mengubah suatu tata cara dalam hal ibadah pada setiap agama yang berbeda dari dasarnya rasa antisipasi, khawatir maupun menghadapi wabah dari covid-19 ini. Sudah banyak orang yang mengurung dirinya di rumah, serta menghindari dari tempat-tempat keramian dan lain sebagainya.

Satuan Tugas Penanganan Covid-19 menghimbau perayaan Hari Raya Waisak yang jatuh pada 26 Mei 2021 tetap menerapkan Protokol Kesehatan. Penyelenggarakan kegiatan pun dapat dilakukan dengan sederhana. "Kami berharap perayaan waisak bagi umat Buddha Indonesia menjadi momentum mendekatkan diri kepada Tuhan Yang Maha Esa. Dan sangat diharapkan, perayaan dan kegiatan ibadah dilakukan dengan disiplin protokol kesehatan," kata Juru Bicara Satgas Covid-19 Wiku Adisasmito di Media Center Covid-19, Graha BNP, Jakarta Selasa (25/05/2021).

Pementrian Agama juga telah mengeluarkan Surat Edaran No. 11 tahun 2021 yang mengatur protokol kesehatan selama rangkaian pelaksanaan ibadah Hari Raya Waisak. Kepada panitia penyelenggara dan umat Buddha di
Indonesia diminta mengikuti protokol kesehatan dan ketentuan lain yang diatur surat edaran tersebut. "Serta selalu mempertimbangan zona resiko bagi yang ingin melakukan kegiatan keagamaan datang langsung ke Vihāra, kebijakan dari pemerintah sudah diganti ibadahnya di rumah sendiri. Dengan mematuhi surat edaran, seluruh rangkaian kegiatan ibadah dapat berlangsung secara aman dan khidmat."

Sebelum pandemi para umat melaksanakan kegiatan dengan jam dan lebih dari waktu yang ditentukan saat berlangsung. Dilakukan bersamasama dengan masyarakat atau keluarga yang ada di rumah dan dapat hadir ke Vihāra tanpa menghawatirkan adanya covid-19. Untuk duduk saat kegiatan berlangsung tidak berjauhan dengan umat lainnya. Dan jumlah umat tidak dibatasi kuotanya. Setelah kegiatan selesai dana paramitta ada salah satu panitia mengelilingi umat dengan membawa kantong khusus dana dan para umat berdana setulusnya.

Dari hasil observasi dan wawancara, peneliti memperoleh informasi bahwa beberapa kegiatan keagamaan di Vihāra Dhammadīpa Surabaya telah mempengaruhi penyelengaraannya seperti Pujabakti umum, Dhammadesana, Meditasi, Sunschool anak-anak dan remaja, Pațidana, Dana makan, Akupuntur gratis, Ritual nikah, Bakti Sosial, Fangshen serta pada hari besar seperti hari raya Māgha Pūja, Vaisak, Asadha, dan Kathina, yang dilakukan secara rutin dengan adanya covid19 pelaksanaan kegiatan diganti secara virtual. Karena adanya pemberlakuan pembatasan kegiatan masyarakat (PPKM) adalah kebijakan pemerintah sejak awal tahun 2020 untuk menangani pandemi Covid-19 di Indonesia. Pemerintah memberikan kebijakan dan larangan untuk tidak berkerumun di Vihāra membuat beberapa umat Buddha di Vihāra Dhammadīpa Surabaya hanya melakukan puja bhakti di rumah masing-masing. Hingga diperpanjang pada tanggal 06 September 2021.

Semua kegiatan dilakukan secara online (dirumah) dan sebagian offline (ditempat kegiatan) namun dibatasi hanya 10 orang. Harus menjaga jarak dan menerapkan protokol kesehatan. Setelah kegiatan tidak boleh kerumunan lagi diminta langsung kembali ke rumah masing-masing. Meskipun menyadari bahaya Covid-19 sangat berbahaya tetapi umat Buddha Vihāra Dhammadīpa Surabaya tidak mengurangi niat 
untuk belajar Dhamma, dengan umat mengikuti secara online. Sengan demikian, untuk kegiatan praktik seperti fangshen, bhakti sosial ke daerah daerah yang biasanya program itu dilakukan 3 bulan sekali, sementara saat ini tidak dapat dilaksanakan. Hal inipun menjadi permasalahan yang sangat penting bagi semua kalangan. Kebutuhan yang semakin banyak namun aktivitas penuh dengan batasan. Sehingga dalam semua kegiatan ini memiliki bagi kegiatan keagamaan yang ada di Vihāra Dhammadīpa Surabaya, yaitu:

\section{Dampak}

Dampak memiliki 2 bagian yaitu dampak positif dan negatif. Dampak positif adalah perubahan yang dapat terjadi pada sebuah tindakan positif, baik disebut juga sebagai dampak yang menguntungkan bagi pihak. Sedangkan dampak negatif adalah sebuah pengaruh yang dihasilkan dari sebuah tindakan yang bersifat merugikan atau memperburuk keadaan (Bejanakehidupan.com).

\section{Dampak Positif}

Berdasarkan hasil observasi dan wawancara mengenai dampak pandemi Covid-19 sangat mempengaruhi kondisi dan situasi selama kegiatan dilaksanakan. Dibawah ini adalah beberapa dampak positif. Sebagai berikut: 1.) Semua diharapkan memiliki jiwa memunculkan kreatifitas dalam teknologi. Sebelum adanya covid-19 dalam melakukan dhammadesana tentunya dilakukan secara offline, akan tetapi adanya pandemi maka dilakukan secara online yang terhubung dengan sebuah aplikasi dan melalui virtual. Dengan demikian mnejadikan umat lebih kreatif dalam teknologi. 2.) Dalam melakukan kegiatan lebih mudah seperti rapat kegiatan Vihāra tidak perlu datang ke Vihāra, diganti melaui online. 3.) Vihāra Dhammadīpa Surabaya membuat gabungan anak-anak kecil membut acara sebulan satu kali bersama antar sekolah minggu di Surabaya.

\section{Dampak Negatif}

Kemudian dampak negatif pandemi covid19 bagi kegiatan keagamaan di Vihāra Dhammadīpa Surabaya. Sebagai berikut: 1.) Spiritual menurun secara perlahan, karena adanya pembatasan keluar rumah dan tidak bisa datang langsung ke Vihāra serta melakukan tatap muka dalam mengikuti kegiatan keagamaan. 2.) Di
Vihāra masih diperbolehkan hadir untuk melakukan kegiatan seperti waisak, tetapi umatnya dibatasi hanya 30-50 persen. Namun disarankan hanya diikuti para bhikkhu dan romo/ramani untuk pemandu acara. 3). Kegiatan puja bakti juga tidak bisa dilakukan karena pindah ke online, sebagian besar umat-umat yang sudah tua tidak bisa join zoom, dan juga koneksi ke youtube keterbatasan tidak memiliki koneksi internet atau kuota tidak ada beberapa umat tidak dapat bergabung. 4.) Minat puja bhakti umat Vihāra Dhammadīpa Surabaya menjadi turun apabila Vihāra mengadakan secara online. 5.) Jika melaksanakan kegiatan secara online itu kendalanya tergantung partisipasan yang ada dizoom. Serta faktor jika tidak ada partisipan aktivitasnya tidak $100 \%$ pun efektif realistis sama dengan zoom online. Dan 75 $\%$ hanya dengan adanya online perlu kita sadari bahwa ketika tidak menyalakan semua camera, kita tidak mengetahui umat benar-benar serius mengikuti kegiatan atau hanya sekedar ikut saja.

\section{KESIMPULAN}

Kesimpulan dari penelitian ini adalah pandemi Covid-19 sebuah virus menyerang sistem pernafasan manusia. Gejala Covid-19 antara lain gejala pernafasan seperti demam, sesak nafas, dan batuk kering. Pemerintah menindak-lanjuti untuk memutuskan penyebaran Covid-19 dengan dilakukan sistem social distancing tetap menjaga kebersihan dengan mencuci tangan setelah melakukan kegiatan, menghidari menyentuh mata, hidung, dan mulut, gunakan masker setiap keluar rumah. Setelah tersebarnya Covid-19 hal ini merubah segala aspek keagamaan, ekonomi, psikologis, dan sebagainya.

Dari hasil wawancara dan observasi menunjukkan bahwa dampak Covid-19 terhadap kegiatan keagamaan di Vihāra Dhammadīpa Surabaya sangat memberi pengaruh positif dan negatif. Kegiatan yang dilaksanakan sebagian besar juga tidak bisa dilakukan secara offline karena diganti ke online, positifnya umat diminta memiliki jiwa yang kreatifitas dalam teknologi, kegiatan menjadi lebih mudah. Sedangkan dampak negatifnya yaitu spiritual mulai menurun, umatumat yang sudah tua tidak dapat join zoom, dan juga kendala dari sinyal untuk koneksi ke zoom atau youtube karena keterbatasan kuota. Solusinya yaitu ada beberapa umat datang ke Vihara namun bergantian. selama pandemi ini. Di Vihāra 
Dhammadipa Surabaya sebelum dan selama pandemic Covid-19 yang akhirnya merubah tatanan serta pola kegiataan keagamaan.

\section{DAFTAR PUSTAKA}

1. Arif, I, S. 2016. Psikologi Positif: pendekatan Saintifik menuju kebahagiaan. Jakarta: PT. Gramedia Pustaka Utama.

2. Burhan, Erlina. Dkk. 2020. Pneumonia Covid19 (Diagnosis dan Penatalaksanaan di Indonesia. Jakarta: Perhimpunan Dokter di Indonesia.

3. Dhammadhiro (penyaji). 2005. Paritta Suci. Jakarta: Yayasan Sangha Theravada Indonesia.

4. Endro, Herman S. 1997. Hari Raya Umat Buddha dan Kalender Buddhis 1996-2026. Jakarta: Yayasan Dhammadīpa Arama

5. Ghony dan Almanshur. 2012. Metode Peneliti Kualitatif. Jogjakarta: Ar-Ruzz Media.

6. Hasan, dkk. 2003. Metodologi Penelitian Kualitatif (Tinjauan Teoritis dan Praktis). Surabaya: Visipress.

7. Hasan, M. Iqbal. 2002. Pokok-Pokok Materi Metodologi Penelitian dan Aplikasinya. Bogor: Ghalia Indonesia.

8. Mahās̄̄ Sayādaw. 2002. Meditasi Vipassana Metode Mahāsī Sayādaw. Terj. Chandasili

9. Meleong, Lexy J. 2001. Metedologi Penelitian Kualitatif. Bandung: Remaja

10.Mon, Mehn Tin. 2012. Intisari Jalan Kesucian (Visuddhi Magga). Terj. Chaidir Thamrin. Medan. Indonesia Tipitaka Center (ITC).

11.Pals, Daniel L. 2018. Seven Theorie Of Religion. Yogyakarta. IRCiSoD.

12.Saldana., Miles dan Huberman.2014. Qualitative Data Analysis. America: SAGE Publication.

13.Sudaryono. 2018.Metodologi Penelitian. Depok: Rajawali Pers

14.Sugiarto. 2017. Metodologi Penelitian Bisnis. Yogyakarta: ANDI

15. Thitaketuko. 2012. Catatan Meditasi Vipassana (Kumpulan Ceramah Dhamma). Denpasar. Tanpa penerbit.

16.Ulber Silalahia. 2012. Metode Penelitian Sosial. Bandung: PT. Refika Aditama

17. Visuddhacara. 1993. Loving and Dying. Malaysian Buddhis Meditation Centre, Sayadaw Malaysia, 119
18.Widyanto, tri. 2011. Jalan membebaskan leluhur dari alam menderita. Yogyakarta: VKD (Vihāra Karangdjati).

\section{Skripsi}

1. Mufidah, fina. 2020. Penangguhan pelaksana Perkawinan pada masa Pandemi Covid-19 Perspektif Maqashid Syari'ah (Studi di KUA Kecamatan Pabelan Kabupaten Semarang). Salatiga: IAIN Salatiga

2. Saputra, johan carly. 2019. Peran Ketua Bhikkhu Daerah Pembinaan Provinsi (Padesanāyaka) Jawa Timur Periode 20182020B Salam Menumbuhkan Persatuan dan Keharmonisan Remaja Buddhis PancaVihāra Surabaya. Malang: STAB Kertarajasa

\section{Jurnal}

1. Beni, Nadjib, Kamal \& Sutiana. Tanpa Tahun. Kesadaran Teologis Keberagaman umat Manusia dalam menghadapi wabah Covid-19. Bandung: Prodi Hukum Ekonomi Syariah

2. Syahputra, Rasayidin, Masganti. 2017. Pembinaan Akhlak Dalam Kegiatan Keagamaan Pada Program Kepramukaan di SMK Tasbiyah Islamiyah Hamparan Perak Kabupaten Deli Serdang. Vol 2. No.2. Edu Religia

3. Toroni, Faiq. 2020. Pembatasan Kegiatan Keagamaan Dalam Penanganan Covid-19. Vol. 6. No. 2. Jurnal Komunikasi Hukum

4. Yuliana. 2020. Corona Virus Diseases (Covid19); sebuah tinjauan literature. Vol. 2. No. 1.p. Wellness and Healthy Magazine.

\section{Website}

1. Abhisarano. 2020. Penerangan Sempurna Buddha Gotama menurut prinsip jarak dan perpindahan (fisika dasar). https://youto.be/1cFbn01k2hI Diakses pada tanggal 05 Maret 2021 12.30 WIB

2. Aditya. 2020. Natal di tengah Pandemi PGI imbau umat Kristiani Ibadah Virtual. https://nasional.kompas.com/read/2020/12/11/ 11400201/natal-di-tengah-pandemi-pgiimbau-umat-kristiani-ibadah-virtual?page $=$ all Diakses Pada tanggal 21 Februari 2021 12.45 WIB

3. Makplus. 2016. Pengertian agama definisi menurut para ahli. http://www.definisipengertian.com/2016/02/pengertian-agama- 
definisi-menurut-ahli.html?m=1 Diakses pada tanggal 14 Maret 2021 18.30 WIB

4. Purnamasari. 2020. Cegah Covid-19 ini anjuran Pemerintah saa lakukan rapat di kantor. https://nasional.kompas.com/read/2020/07/19/ 18394751/cegah-covid-19-ini-anjuranpemerintah-saat-lakukan-rapat-di-kantor Diakses pada tanggal 10 Maret 202108.30 WIB

5. Pranita. 2020. Diumumkan Awal Maret, Ahli: Virus Corona Mauk Indonesia dari Januari. https://www.kompas.com/sains/read/2020/05/ 11/130600623/diumumkan-awal-maret-ahli-virus-corona-masuk-indonesia-dari-januari

Diakses pada tanggal 07 Maret 202118.35 WIB

6. _ 2020. Māgha Pūja lebih dari sekadar peringati 4 peristiwa langka dalam sehari. Https://berita.bhagavant.com/2020/02/08/mag ha-puja-lebih-dari-sekadar-peringati-4peristiwa-langka-dalam-sehari.html Diakses pada tanggal 10 Maret 2021 02.30 WIB

7. _ 2016. Anak-anak Buddhis ikuti Puja Bakti di Vihāra. https://kaltim.kemenag.go.id/berita/read/41299 8 Diakses pada tanggal 08 Maret 202106.07 WIB

8. _ 2020. Dampak positif dan negatif virus yang bisa menjadi pelajaran. Https://www.unpak.ac.id/corona/dampakpositif-dan-negatif-virus-corona Diakses pada tanggal 07 Maret 2021 19.30 WIB

9. _ 2019. Kegiatan Rutin.

Http://www.VihāraDhammadīpa.com/kegiata n-rutin/ Diakses pada tanggal 05 Maret 2021 $08.30 \mathrm{WIB}$ 